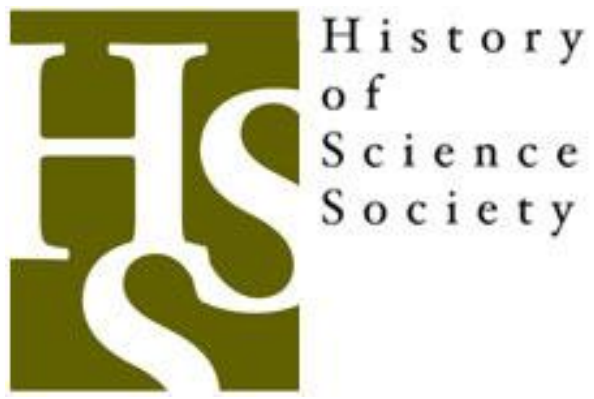

Review

Author(s): Gary Hatfield

Review by: Gary Hatfield

Source: Isis, Vol. 81, No. 3 (Sep., 1990), pp. 574-575

Published by: University of Chicago Press on behalf of History of Science Society

Stable URL: http://www.jstor.org/stable/233462

Accessed: 24-11-2015 19:02 UTC

Your use of the JSTOR archive indicates your acceptance of the Terms \& Conditions of Use, available at http://www.jstor.org/page/ info/about/policies/terms.jsp

JSTOR is a not-for-profit service that helps scholars, researchers, and students discover, use, and build upon a wide range of content in a trusted digital archive. We use information technology and tools to increase productivity and facilitate new forms of scholarship. For more information about JSTOR, please contact support@jstor.org. 
of curves, with its references to "all the lines over (or under) a segment," as unproblematic both mathematically and historically. Yet it was a relatively new technique at the time and rested on a tricky adjustment of Bonaventura Cavalieri's method of indivisibles. One wonders how Huygens learned of it. In Chapter 7 on rectification, Yoder presents van Heuraet's application of the technique to reduce the rectification of a curve to the quadrature of another and contrasts the procedure with Huygens's method of determining normals to the involute, as if the two approaches solved the same problem and as if Huygens's were both as direct and as universal as he claimed. Only at the end of the chapter does one learn that Huygens's method only works if one happens to recognize the involute of the curve to be rectified and that, in fact, the reduction to quadrature cannot be avoided.

But these are minor flaws in an otherwise excellent account that should bring Huygens more directly into general view. It is good to have this book. Unfortunately, as we have come to expect of Cambridge University Press, its price is outrageous.

MichaEL S. MAHONEY

\section{Eighteenth Century}

Manfred Kuehn. Scottish Common Sense in Germany, 1768-1800: A Contribution to the History of Critical Philosophy. (McGillQueen's Studies in the History of Ideas.) xiv + 300 pp., app., bibl., index. Kingston, Ont./Montreal: McGill-Queen's University Press, 1987. \$35.

Manfred Kuehn's book is intended to provide a broad survey of the effects of eighteenth-century Scottish commonsense philosophy on German philosophy in the period from 1768 to 1800 (from the first glimmerings of Kant's critical philosophy to the end of his active period, before his death in 1804). It argues for two related theses: that Scottish commonsense philosophy-the philosophy of Thomas Reid, James Oswald, and James Beattie-was much better known, and much more influential, in German philosophy during this period than has been recognized in scholarship of late; and that Kant's critical philosophy and the philosophical positions of Kant's important interlocutors, including
Johann Nicolaus Tetens, had more affinities with Scottish philosophy than has been realized hitherto.

Kuehn mounts an impressive scholarly argument that firmly establishes that the work of Reid, Oswald, and Beattie was much discussed, regularly translated, and sometimes admired by German philosophers during the period in question. He contends that especially in the years prior to Kant's notorious condemnation of the three Scots in his Prolegomena to Any Future Metaphysics of 1783, their work attracted much interest because it was considered to provide an antidote to the skepticism and idealism of George Berkeley and David Hume. Beginning in the 1780s, German philosophers looked to Kant to fill that function-or they at least acknowledged his work as the dominant bid in that game. This is where Kuehn's second thesis becomes important. He maintains that even if Kant's work came to dominate philosophical discussion in Germany, this was only a nominal lessening of the influence of the three Scots, for, Kuehn argues, Kant himself was heavily in their debt. In accordance with R. G. Collingwood's suggestion that vehement rejection can be a sign that an author is in reality strongly attracted to the views he ostentatiously denounces, Kuehn contends that Kant was strongly attracted to the views of commonsense philosophy. Here his argument is less secure. For although he establishes that commonsense philosophy was widely discussed during the 1770 s, he does not show that Kant took part; and although he shows that some of Kant's contemporaries compared his response to Humean skepticism with the positions of Reid and his cohort, he is on weaker ground in arguing that this contemporary perception was near the mark.

Kuehn's proposal of a strong "commonsense" influence on Kant cannot be examined adequately in the space allotted here. But in any evaluation of this proposal, close attention must be paid to the claim that what the Scots called "inborn principles of belief" are similar to Kant's a priori principles of the understanding. Further, in any evaluation of Kuehn's claim that Tetens's analysis of the human understanding was quite similar to Reid's, close scrutiny should be given to the implied similarity between Reid's postulation of an inborn inclination to believe in the external world 
and Tetens's postulation of basic laws of the understanding as conditions for the possibility of objective thought. My own belief is that the similarities are not sufficient to support Kuehn's second thesis.

Despite the fact that, in my view, the book does not establish one of its two principal theses, I commend it to those with an interest in German philosophy during this period, and to those with an interest in the history of the human sciences. Moreover, Kuehn's establishment of Scottish influence in Germany-including reviews of books published in English and their subsequent translation-can serve as a reminder to scholars of the seventeenth and eighteenth centuries of the danger of "national histories" that ignore the international character of the community of natural and moral philosophers during the Enlightenment.

GARY HATFIELD

Johann Heinrich Lambert. Texte zur Systematologie und zur Theorie der wissenschaftlichen Erkenntnis. Edited by Geo Siegwart. Textual editing by Horst D. Brandt. (Philosophische Bibliothek, 406.) ci +160 pp., index. Hamburg: Felix Meiner Verlag, 1988. DM 48 (paper).

Most historians of science know of $\mathbf{J}$. $\mathrm{H}$. Lambert from his Cosmological Letters or from the mathematical series that bears his name. The three texts presented here, selected for inclusion in the Philosophische Bibliothek series of classical works, have as their focus Lambert's little known, but extremely interesting, thoughts on the philosophy of science. Further, the emphasis is on Lambert's ideas for their own sake, not, as is too often true, for their relation to or influence on Kant's thought.

Geo Siegwart has provided an eightyseven-page introduction in which he explains and justifies his choice of texts from Lambert's works. Following a brief sketch of Lambert's humble beginnings, his eccentric personality, his work in natural science, and the development of his uncomfortable position among the elite in German society, Siegwart discusses Lambert's achievements in philosophy of science. His goal, as is evident from the title, is to bring to the fore selections that highlight what Geron Wolters has identified as the two aspects of Lambert's approach, one se- mantic and the other syntactic. Needless to say, these two aspects are related: the former deals with what scientific propositions are talking about while the latter is concerned with their interconnection.

Lambert, like Kant, began with Christian Wolff's compendium of Leibnizian philosophy, though unlike Kant he did not attend a university and was for the most part selftaught. Lambert found Wolff's system impressive in its recognition of the power of deduction, but he became completely unsatisfied with its treatment of the so-called Anfangsproblem, that is, how one justifies the starting points of deduction. It is in pursuit of the solution to this problem that Lambert's pragmatic theory of scientific knowledge and his systematology emerge.

Siegwart has drawn on three of Lambert's works. The first two, published during his lifetime, are the New Organon, or Thoughts on the Investigation and Designation of the True and Its Distinction from Error and Illusion (1764) and the Design for an Architectonic, or Theory of Simple and First Things in Philosophical and Mathematical Knowledge. Though completed by 1764, the Architectonic appeared first in 1771 because publishers were concerned about the difficulty of the work. The third text is more problematical. In a letter from 1767 Lambert referred to a "sketch of a systematology" that he had written down for himself. Siegwart argues that this reference must be to a manuscript entitled "Fragment of a Systematology" that was included in the second volume of Lambert's essays, edited by the astronomer Johann Bernoulli in 1787.

In his introduction Siegwart provides helpful overviews of both the Organon and the Architectonic. The latter, he argues, can be seen as a branch of science in which the results of the former are applied. But it is to the Architectonic that Lambert refers in the Fragment; hence, according to Siegwart, we must focus on the relation between these two works for Lambert's contribution to system theory. This he does en route to his conclusion that no one before Lambert treated the notion of system at such a general level or in such a detailed fashion. Others have pointed out that although Lambert's focus on system did not completely exclude a concern for ontological realism, his emphasis clearly anticipated an instrumentalist interpretation of science and a coherence theory of truth. It 